\title{
THE STRATEGIES OF USING VIRTUAL COMMUNITIES IN BUILDING CUSTOMER CAPITAL
}

\author{
Wiesława Caputa* \\ Silesian University of Technology/ Department of Organization and Management
}

\begin{abstract}
In the conditions of growing demand and rising barriers to customer requirements, the key competence of the company that determines its duration and development, is the ability to create the customer capital. This ability is directly related to the building and transferring of knowledge. The customers are becoming a source of knowledge for the enterprise more and more, who create their own initiative or are inspired by the enterprise. Virtual communities are embroiled in a web of relationships enabling interactive communication message, the content of which can be used in the process of: design, manufacturing, delivery and communication of values. Realizing the potential of virtual community generates business opportunities to create a unique product. Such a product meeting the functional and emotional tasks defined by the customer, is created on the basis of relationships grounding on cooperation and commitment of the customer, which positively reflect the stability of the relationship, and thus reduce the risk of capital engagement. The research on changes in attitudes and behavior of customers and on the emerging challenges for the company, identified the opportunities and barriers of building the knowledge base with the help of virtual communities and show that the effective use of the potential of virtual communities in the process of customer capital creation requires not only the development and implementation of strategy integrated with the global strategy of the company but also building an organizational culture open to the implementation of the customer's interest. The verification of the hypothesis is based on the analysis of scientific research centers and other studies in the literature.
\end{abstract}

Keywords: knowledge resources, customer capital, virtual community

\section{Introduction}

The XXI century is the century of a turbulent change: technical and technological information revolution, intensifying processes of globalization, but above all, the age of the struggle for the customer. The crisis of overproduction, accompanied by: a steady increase in the number of suppliers capable of providing essentially all of the expected customer value, after getting a lower satisfaction cost, implies a radical change used so far to compete (Kaplan and Norton, 2002, pp. 22-23). Quick implementation of new technologies, perfect financial management, increase of productivity, improvement of standards, realization of economies of scale or maximum standardization are the conditions necessary but not sufficient for the protection of long-term supply of capital for the company (Doligarski, 2006, p. 433). In the new conditions of source management of competitive advantage is no longer the quality of the product, not even customer satisfaction created by delivering the value expected, but it becomes a lasting relationship with the customer, based on loyalty and profitability.

The value of that relationship is identified with customer capital, which in essence reflects the economic utility of the customer. This utility is inextricably linked to the market and resource potential of the customer, and therefore with his/her ability and willingness to direct and indirect capital supply, which ultimately translates into the customer value for the company and the value of the company itself (Caputa, 2015a, pp.14-15). An important determinant of that power is the duration of the relationship. When striving to maximize the benefits coming from the capital engaged, the company faces

Corresponding Author: *Caputa.w@wp.pl 
the necessity of not only acquiring the customer, but also to maintain and develop this relationship in the long term. The road to this goal is to build satisfaction, intimacy, trust and customer engagement (Prahaland and Ramaswamy, 2000, p.80, Rudawska, 2008, pp.178-190).

Creating and maintaining the advantage based on profitable and permanent relationship with the customers in the conditions of increasing demand barrier, requires offering a unique product on the market that the customer selects from the whole mass of others, guided by the subjective and variable criteria, which go far beyond the nature of the product (Doyle, 2003, pp.270-272, Bielecki, 2006, p.257, Caputa, 2015b, pp. 77-79). A unique product is the company's reply to the needs of the customer, which in the subjective customer's assessment solves problems better than the competitive products (Caputa, 2016). Creation of such a product is not easy, especially that, the above mentioned changes also had an impact on the attitude and customer behavior, and it is so clear that today it is commonly spoken about the phenomena of the "new consumption" (Bywalec, 2007, p.137), or "intelligent consumption" (Havas Prosumer Report, 2014). As a result, customers today are: educated, aware, active and increasingly demanding participants of the market game. When making decisions about the capital supply for the company, they evaluate not only the final result of the company's activity through the prism of their experience and information from other market participants, but they evaluate the whole process of creating, delivering and communicating on the market, in the context of its impact on the environment and compliance with ethics, resulting in the greening of consumption. They more and more often direct their spending to meeting the needs of a higher order, which results in servicing and dematerialization of consumption. They manage time, waiting for the possibility of transferring the places of meeting the needs from public institutions to the private space and accessing them at any time. They also look to a free choice of information contents, as well as creating and offering their own content to other customers, which translates into an increase in virtualization of consumption. They expect a personalized offer and are willing to participate actively in the process of its creation, which confirms the growing phenomenon prosumerism.
As it stems from the above, the creation, delivery and communication of a unique product on the market of in the conditions of growing price pressure, forces the companies to develop new skills, the effect of which is primarily to understand the customer, and thus provide them with the expected values: faster, better, more convenient and cheaper (Caputa, 2015b, p. 57). The starting point for achieving this objective is to obtain information and resources to generate awareness about the value that determines the user (customer) satisfaction. In consequence, the source of knowledge for the enterprise are becoming the customers more and more often who, using their own initiative or inspiration from the enterprise itself, establish virtual communities and become caught up in a web of relationships enabling interactive communication transfer, the content of which can be applied in the process of value creation. This explains the growing activity of enterprises in terms of the utilization and development of the resource potential of online communities (Gassmann et al., 2012, p.175).

From the perspective of conducting business activity a fundamental issue, however, is not whether to use these communities, but how to use them to maximize the benefits of the capital employed? The main objective of the work is to identify the opportunities and barriers of building the knowledge base with the help of virtual communities and to verify the thesis assuming that the effective utilization of the resource potential of virtual communities in the process of customer capital creation requires developing a strategy and establishing the organizational culture open to the realization of the customer's interest. The verification of the hypothesis is based on the analysis of the experiences of selected companies, other research centers and literature review.

\section{The essence and classification of virtual communities}

The dynamic development of information and computer technology, including the Internet, contributed to the development of virtual communities. In general, this community can be defined as a social network that uses computers to establish, maintain and develop relationships and within the group builds a network of relationships where certain characteristics are the junction of common community creating them. As a result, the 
Internet community is characterized by: using a computer to establish a relationship, often lack of the ties of territorial homogeneity concerning the interests, values, ideas and attitudes of their members, heterogeneity in terms of age, social status and other factors, status, independence and freedom of choice (Wellman and Gulia, 1997, p. 15).
Differentiation of the virtual community generates the possibility of introducing a number of criteria characterizing the various communities, their synthetic overview is included in table 1.

Table 1 The selected criteria for the classification of online communities

\begin{tabular}{|c|c|}
\hline Criterion & Division \\
\hline Place of functioning & $\begin{array}{l}\text { - Operating exclusively on the } \\
\text { Internet } \\
\text { - Transferring its activities outside } \\
\text { the network }\end{array}$ \\
\hline \multirow[t]{2}{*}{ Purpose of activity } & $\begin{array}{l}\text { - Focusing on building } \\
\text { relationships }\end{array}$ \\
\hline & $\begin{array}{l}\text { - Focusing on the execution of a } \\
\text { particular task }\end{array}$ \\
\hline Population & $\begin{array}{l}\text { - Small amount, e.g. blogs, } \\
\text { - Large, e.g. social networking } \\
\text { sites }\end{array}$ \\
\hline \multirow{3}{*}{ Phases of life cycle } & - Newly emerging, \\
\hline & $\begin{array}{l}\text { - During the period of growth and } \\
\text { development }\end{array}$ \\
\hline & - Period of stagnation and decline \\
\hline \multirow[b]{2}{*}{ Culture members } & - Monocultural \\
\hline & - Multicultural \\
\hline Age members & $\begin{array}{l}\text { - Created by children and young } \\
\text { people, e.g. aged } 20-30 \text { years, or } \\
\text { created by older people }\end{array}$ \\
\hline
\end{tabular}

Source: own work

The criteria above do not exhaust the existing possibilities, but also characterize the Internet community in one dimension. When analyzing the opportunities and barriers of using the virtual communities in the process of customer capital creation, it is worth introducing such typology which characterizes them through the community relationship with the real world, and also relates to their characteristics such as: how the assumptions and the type of relationships bind the community. The types of virtual communities distinguished on this basis are presented in figure 1 . 


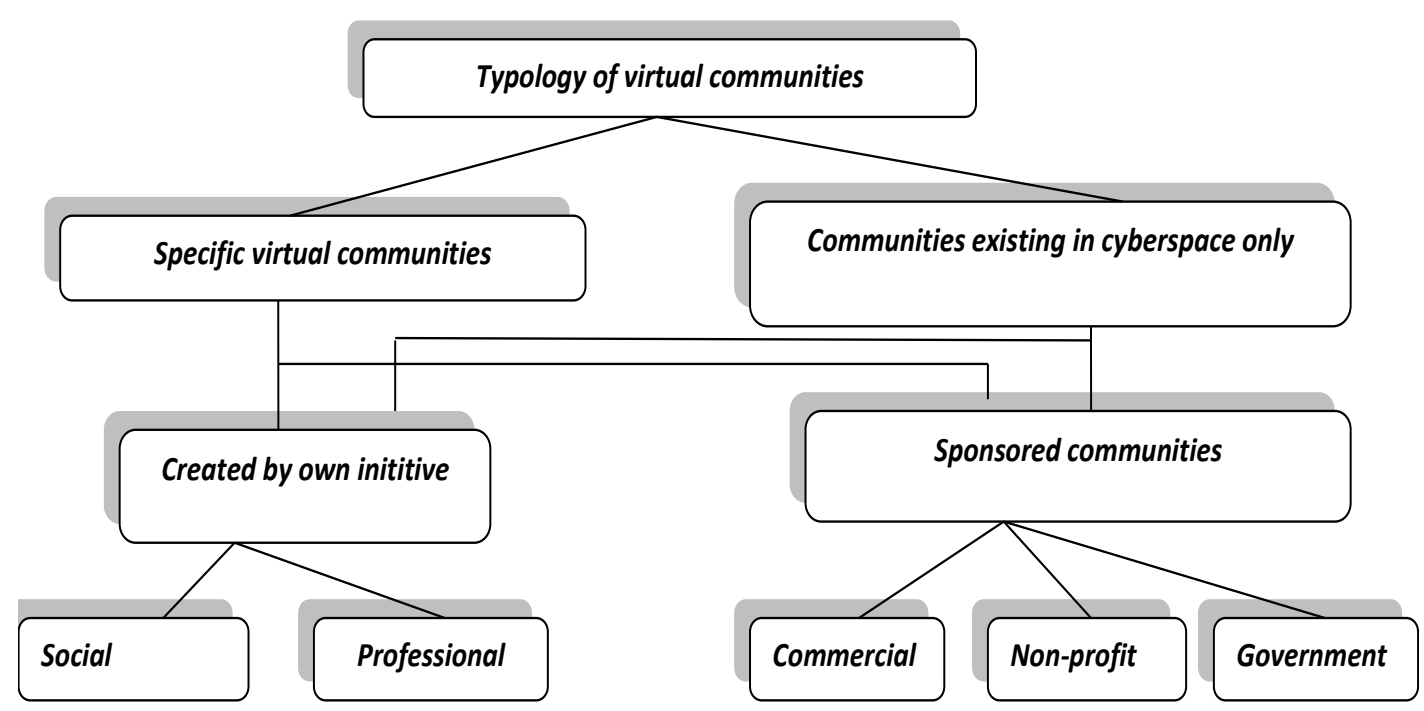

Figure 1: Types of online communities

Source: own work based on: Tang and Yang, 2006, Koss, 2010, p.528

The specific virtual communities in their essence are an extension of the real world communities. Communities are based on the relationships that were established in the real world, and then used in the Internet to be refreshed, maintained and developed. In these communities the relationships may be based on:

- solidarity, e.g. family, ethnic group,

- interactions in which the relationships linking people with more than what is necessary occur. These informal relationships lead people to interact, e.g. groups using the Internet to organize protests,

- common institution established on the basis of membership in a social category, the example of which may be the tribe of North American Indians, Oneida, that became a nation thanks to the Internet (Burszta, 2003, p.162).

The communities that exist only in cyberspace emerge regardless of human relationships outside the network and their bond are common interests, beliefs and values. Participation in these communities is the most common manifestation of satisfying the needs of people belonging to some group and building their identity in this way. It should be emphasized here that the emergence of such communities does not exclude the possibility of transferring the relationships established virtually to the real world.

The online communities can be formed by the initiative of the participants and base on family relationships, friendly or social (professional) ties and also may be of sponsored character. In this case, they are set up and managed by a third party (sponsor), and the relationships established and developed in the group include both the relationships between members of the forum, as well as of the sponsoring organization. Creating this type of community is not accidental and is closely related to the implementation of the objectives that is defined by the sponsor.

Regardless of their classification, online communities are a gathering of people who participate in them to satisfy their needs. Referring to the definition of community by B. Wellman, who treats it as a "source of social life, support, information, a sense of belonging and social identity" (Wellman and Gulia, 1997). The features of online communities can be defined. It should be noted, however, that they take place via computer and the Internet, which requires the use of social media appropriate to the needs of users. As a result, based on the relevant criteria the model division of online communities may be 
Table 2 Classification of online communities, taking into account the needs of users and functions of social media

\begin{tabular}{lll}
\hline USER NEEDS & $\begin{array}{l}\text { FUNCTIONS PERFORMED BY } \\
\text { SOCIAL MEDIA }\end{array}$ & SOCIAL MEDIA \\
\hline $\begin{array}{l}\text { Free access to message } \\
\text { content creation and } \\
\text { delivery }\end{array}$ & $\begin{array}{l}\text { Serving for opinions and views } \\
\text { publication (presentation) }\end{array}$ & $\begin{array}{l}\text { Blogs, Wiki, Citizen, } \\
\text { Journalism }\end{array}$ \\
\hline Resources co-sharing & $\begin{array}{l}\text { Used for building a base of transferable } \\
\text { resources and stored in cloud }\end{array}$ & Youtube, Flicr, Slideshare \\
\hline $\begin{array}{l}\text { Cooperation and } \\
\text { collaboration to achieve a } \\
\text { defined purpose in a } \\
\text { carefully selected (most } \\
\text { often closed) group }\end{array}$ & $\begin{array}{l}\text { Used for co-creation or/and cooperation } \\
\text { aimed at achievement of a defined } \\
\text { objective (collective intelligence) }\end{array}$ & Google, Docs, MMO \\
\hline $\begin{array}{l}\text { Interpersonal } \\
\text { relationships } \\
\text { establishment and } \\
\text { development }\end{array}$ & $\begin{array}{l}\text { Used for interpersonal relationships } \\
\text { establishment and maintenance }\end{array}$ & $\begin{array}{l}\text { Social Networking, Virtual } \\
\text { world }\end{array}$ \\
\hline $\begin{array}{l}\text { Views exchange, } \\
\text { expressing opinions }\end{array}$ & $\begin{array}{l}\text { Serving for communication and } \\
\text { discussion }\end{array}$ & $\begin{array}{l}\text { Instant Messaging, Forums, } \\
\text { Chats }\end{array}$ \\
\hline $\begin{array}{l}\text { Sharing information } \\
\text { related to the current } \\
\text { events }\end{array}$ & $\begin{array}{l}\text { Used for ongoing information transfer } \\
\text { and news reporting }\end{array}$ & $\begin{array}{l}\text { Mikroblogs, citizen notices, } \\
\text { Livecast, Livestream }\end{array}$ \\
\hline
\end{tabular}

Source: own work

When characterizing the Internet community the attention should also be paid to the type of users participation in the social media in the process of constructing and transmitting the media content. The user of the social media, on the basis of formal or informal premises, may play the role of:

- consecutive relays transmitting specific information further to a defined recipient or to an unidentified group of people,

- verifier of media contents published in the old and new media, generated by both mainstream media as well as non-professional users,

- adding a comment (of different length and substantial quality) to the media content,
- creator of the message who prepares and publishes new contents,

- passive recipient of information (Nowak, 2012).

The role that the participant in an online community serves in the network of relationships has a significant impact on the assessment of the information and reference potential, as the information sender. It translates into: quality of information, information efficiency, and consequently, the effectiveness of communication (Cornelsen, 2000, p.199, Fridriechs-Schmidt, 2006, p.1,). As a result, the roles taken or accepted may contribute to the success or failure of the particular forum (Tang and Yang, 2006).

\section{Opportunities and barriers of using online communities in customer capital creation}

The communities indicated, grounding on a network of relationships used to meet the needs of their members, can be successfully adopted in the 
customer capital creation. Referring to the paradigm of accounting, that is the resource, and financial description of phenomena, this capital can be defined as a collection of intangible assets inherent in the current and potential customer base, whose value reflects the stream of future cash flows generated by the company in connection with the delivery of customer value in the whole potential period of the maintenance of this relationship (Caputa, 2015b, p.73). On one hand, we deal with the customer potential in terms of company capital supply, and on the other hand with the potential of the company to meet customer requirements.

The customer potential, reflecting the value for the company, is inextricably linked to customer willingness and ability to provide capital in a direct and indirect way. The direct supply, remaining in connection with the customer income and development potential, is the result of transactional customer relationships. In contrast, indirect supply is the result of one or two-way flow of information, which may take place in a group of customers as well as between the customers and the enterprise (Tomczak and Rudolf-Sipötz, 2003, p.138, Schneider, 2007, p.116).

Taking the benefits into account of the information flow among the designated parties indicated in table 3 , it is not difficult to verify that, regardless of whether the flow is based on the social or business relationship, its effects can translate into the value of relationships assessed by both parties, and consequently, into their duration. The result of this flow is in fact: increase in the possibility of generating a stream of revenue, reduce the costs and the stream of capital engaged.

Table 3 Selected benefits resulting from the flow of information in "company-customer", "customer-company" relationships

\begin{tabular}{|c|c|c|}
\hline & $\begin{array}{l}\text { Communication in "customer-customer" social } \\
\text { relationships }\end{array}$ & $\begin{array}{l}\text { Transmission of information in business } \\
\text { relationships: } \\
\text { "Customer - company" - } \\
\text { "Company - customer" }\end{array}$ \\
\hline 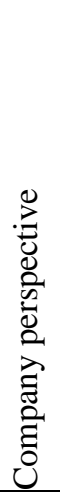 & $\begin{array}{l}\text { - acquisition of additional customers, } \\
\text { - reduction of the cost of acquiring customers, } \\
\text { - increase of the possibility of reinvesting } \\
\text { profits, } \\
\text { - risk reduction of resources engagement in } \\
\text { activities that are not actively approved by the } \\
\text { customer, } \\
\text { - building trust and reputation of the company, } \\
\text { - increase of the stability of business } \\
\text { relationships, }\end{array}$ & $\begin{array}{l}\text { support for the process of recognizing and } \\
\text { understanding the requirements of customers, } \\
\text { - limitation of the impact of variability on the } \\
\text { innovation process undertaken in the company, } \\
\text { - directing the activities and processes taking place } \\
\text { in the company to customer value creation, } \\
\text { - adjusting business production potential to the } \\
\text { changing requirements of the environment, } \\
\text { - strengthening and developing the existing } \\
\text { knowledge resources, including through the } \\
\text { relationship use and extending the range of its } \\
\text { users. }\end{array}$ \\
\hline 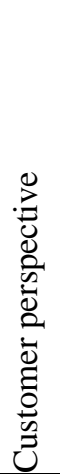 & $\begin{array}{l}\text { - obtaining information about the characteristics } \\
\text { of the product and service quality supported by } \\
\text { the experiences of other customers } \\
\text { - reducing the time of searching for the product, } \\
\text { - reducing the risk of selecting the product } \\
\text { incompliant with customer requirements, } \\
\text { - strengthening the confidence in the product } \\
\text { and the company, }\end{array}$ & $\begin{array}{l}\text { the opportunity to purchase the product solving the } \\
\text { multidimensional "customer problems" } \\
\text { strengthening and developing the existing } \\
\text { knowledge resources about the product, its } \\
\text { manufacturing and the company, } \\
\text { the opportunity to actively participate in the } \\
\text { manufacturing, delivery and communication of the } \\
\text { product on the market, } \\
\text { the opportunity to establish close relationships } \\
\text { based on satisfaction relationship with the } \\
\text { company. }\end{array}$ \\
\hline
\end{tabular}

Source: own work 
When striving to maximize the benefits coming from the capital engaged, the companies should see the customer not as a passive purchaser of the offer, but a resource whose knowledge potential properly used and developed contributes to the increase in the company value. In this moment it should be emphasized that the acquisition and development of customer knowledge resources in the conditions of growing demand barrier is of fundamental importance. Supplying the company with capital is not possible without gaining the customer, what in turn forces the willingness and ability of the company to address the functional and emotional tasks systematically, posed by the desirable customer from the perspective of the objectives achievement in the particular exchange conditions. Moreover, the company must cope with this task faster and better than the competition. This is impossible without the customer, who on the one hand is the addressee and user knowledge of the activities undertaken in the enterprise and, on the other hand she/he is an architect of these activities, determining, through the acquisition of a product, which activities create value and which are "empty", thus she/he becomes the censor of knowledge embodied in the products offered (Caputa, 2008, pp.165-177). In consequence, knowledge becomes the basis of the relationship linking the customer with the company, which determines the capital supply (fig. 2).

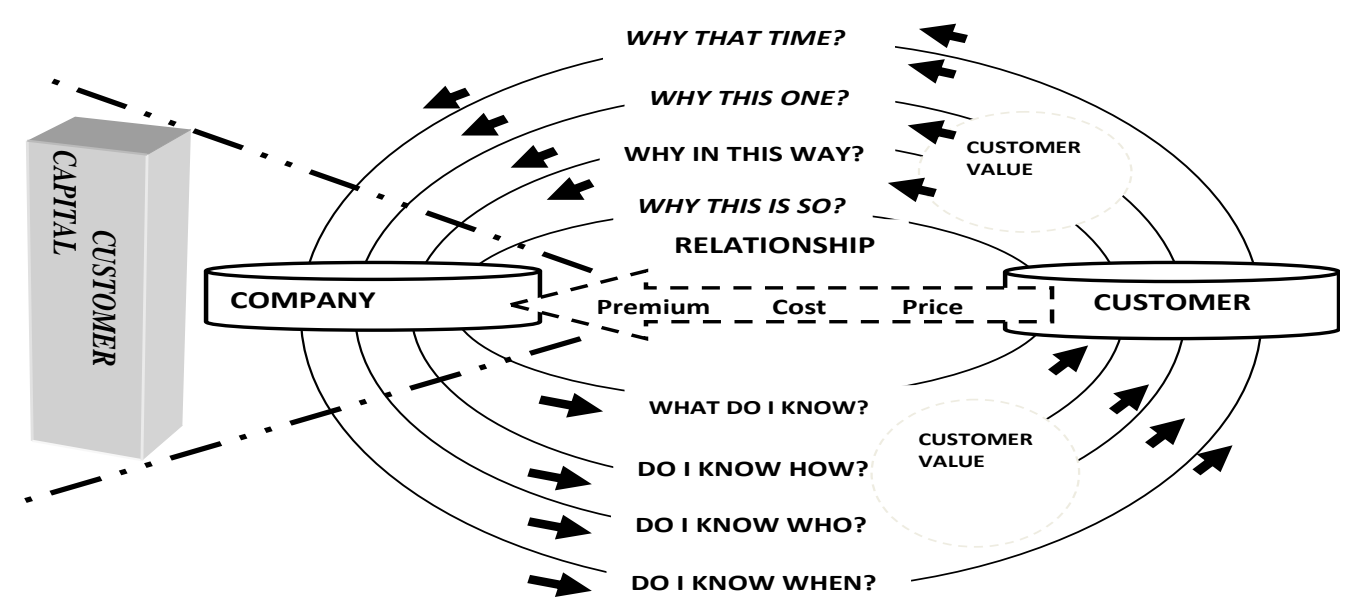

Figure 2 Knowledge as the basis of the relationship linking the customer with the company

Source: own work

When speaking of enterprise's customers and the possibility of using their knowledge in the process of company value creation using the online communities, one must step outside a narrow understanding of the customer as a buyer who has the final product offered by the company and accept the definition used in the concept of TQM. According to this concept, the customer is "any person who pays and/or uses the product after it is delivered" (Sandholm, 1997, p.59). As a result, this category includes not only the entity that buys the product on the market, but also:

- people who receive or benefit from the work of someone else, enriching it with their own contribution in the context of a process or activity (so-called internal client),

- bodies representing the company on the market, being the participants of the distribution channel (socalled agent),

- entities currently using the product offered by the company,

- society, that is the group purchasing the company 
products (Szczepańska, 2010, p.270).

The need to extend the range of customers outside those buying and consuming products comes from the very nature of online communities, where the participants do not have to be affiliated with a company by a transactional relationship and the resulting experiences or even the intent to establish the relationship, what does not rule out their participation in the process of customer and company value creation. When keeping other relationships with the company, e.g. employees, suppliers, members of virtual communities, they may possess the knowledge which can be successfully applied in the design, creation, distribution and communication of values. The participants of virtual community may, for example:

1. define the functional characteristics of the product, which directs the activities and measures leading to its production at an early stage, enabling the management of costs and efficiency in the product life cycle,

2. test the product indicating its weaknesses, what allows the elimination of defects before starting the production process or services,

3 . indicate the way of process organization, perform the operations or activities that reduce the cost of the resources engagement,

4. provide information about the product, what allows distinguishing the product from other ones available on the market and create brand awareness,

5. provide information about the company, its activities, commitment to the needs of local communities, etc. (Szwajca and Gorczyńska, 2013),
6. image of the brands offered as well as the reputation of the seller.

The effects above can also be achieved through a direct contact with the customer or the use of traditional media to gather and transmit information. However, an undeniable advantage of virtual communities is the ability to gather and transmit a large amount of information to a geographically dispersed group of people in real time, at relatively low capital outlays. Nevertheless, one cannot forget that the participants of virtual communities are characterized by different activity and different knowledge potential. The motivations of participation, information gathering and transmission in the network are also diversified, as well as the power of such message. In consequence, the potential of the network in the process of customer capital creation cannot be judged only by the number of participants (Caputa, 2016, p. 133)

Each of the above mentioned features differentiating the participants of the network can also be a barrier at the same time for the use of these communities in the process of customer capital creation. The passivity of network participant has a negative impact on his/her attitude and behavior, especially as: a sender, relay and creator of information gathered. Also the reception of information broadcast by other participants, that are obtained without emotional involvement, is difficult to combine with the concept of loyalty, and thus it is hard to transfer it into a repetitive purchasing behavior of the participant. Indeed, the inertia of the participant does not have to eliminate him/her as a source of company capital supply, especially in the short term (Bliemel and Eggert, 1998).

A significant barrier of using the Internet community may also be motivations. The participant satisfies the needs by joining the community. If these needs remain in relation with, among others, desire of belonging to the community, active participation in the exchange of information or identity building, the participant will be willing to be active, which can be reflected in: willingness to share experiences, recommending a product, transfer of knowledge about the possibility of solving a particular task, sharing own ideas or testing new solutions, product or 
even an idea. If, however, his/her motivations come down to solving a specific, individual problem such as: filling in the questionnaire, its usefulness as a provider of indirect capital supply for the company is negligible.

From the perspective of achievement of the company objectives, the most significant barriers of using the virtual communities in the process of customer capital creation is not only the readiness of a participant to use of launch the information transfer, but also the ability to create, process and transmit information. This ability is in a direct connection with: knowledge resources, their launch allows the participant of the community to start information transfer with unique quality and power of such transfer, which translates into its effectiveness.

The value of knowledge resources that the network participant has at disposal is assessed by its user in each case. Thus the network participant will be considered as a source of company capital supply, only when he/she possesses such information resources that can contribute to the process of company value creation. This contribution remains in connection with both frequency and power of transferred references and recommendations, as well as information that the company uses itself in the process of identification and resolution of functional and emotional customer's problems in a way allowing minimizing the cost of his/her satisfaction. Special importance is gained by such network participants, who can play a role of so-called lead user or opinion leaders. Lead user is such user of the products offered by the company, who not only possesses information about the needs, but also how to resolve the customer's problem (Reichwald and Piller, 2006, p.126).

Therefore, the participant in the network has a high awareness of the problems and possesses the ideas correspondent with the needs, that most users will come into contact in the future (von Hippel, 1986, p.79,1Herstatt, 1991, pp.131-133).

As a result, the company may treat such an entity as a kind of laboratory of ideas, whose knowledge and skills properly used support the process of creating value, in particular, among others, by: reducing risks and uncertainties of own innovation process, shortening the time from the start of work on the product until the product launch, increasing the degree of product innovation noticed by the customer, increasing the positive attitude of the buyer to the products offered by the company (Franke and Piller, 2004, p.6, Reichwald and Piller, 2006, p. 57, Szneider, 2007, p.161). It should be emphasized that such a member of the community is not only attractive as a supplier of information and co-creator of value, but also as an entity of reference potential. As a user, who is distinguished by readiness to launch innovation aimed at solving a specific problems, what results in own solutions, by providing references she/he is able to influence the attitudes and buying behavior effectively of other members of the network. Reputation lies at the core of the high reference potential of the entity, coming primarily from his/her practical experience supported by expertise that translates into reliability of the information provided. In effect, lead user is a provider of information, not only with high quality parameters but also in certain circumstances it may be characterized by high information performance. This performance, however, is determined by a network of social relationships, that the informant establishes in the environment and his/her position in the network. A special position in the network is taken by so-called opinion leader, that is an entity, that strengthens the credibility of the information provided informally, at the same time she/he may influence the behavior of others. Leader's reputation lies at the basis of this communication, coming from his/her personality and professional knowledge, which in turn means that his/her views and behavior serve as the basis of orientation for the others (Vernette, 2004, p.90, Roch, 2005, pp.110-131). Opinion leaders thus create a visible point - relay station in the information network, which makes it possible to spread information and reach out to a wider audience. It should be noted, however, that the leader, in order to maintain his/her position must act as guardian, and therefore decide which information is reliable and will be accepted by him/her and passed on. She/he must act as a leader as long as his/her opinion will have an impact on the attitudes and behavior of other entities. 


\section{Strategy of social prestige in creating the resource potential of virtual community}

The possibilities of leaders and users, stemming from the power of transfer, definitely indicate that the company, leading to effective utilization of virtual communities in the process of customer value creation, should take a position of an expert itself. This, in turn, rises the necessity of directing the activities to building such relationships with business stakeholders that ground on trust and corporate reputation. This direction of activities is also justified by the fact that the information transfer cannot be fully controlled within the frames of communities. Nevertheless, the company that has good reputation may effectively participate in views exchange, contributing to enrichment of discussion with the threads introduced, and what follows it, effectively affect the attitudes and behavior of message recipients. In this context it is worth mentioning the research on "Confidence barometer" from year 2008 and similar research conducted in 2010. In the first period mentioned, $58 \%$ of respondents confirmed that they trust the companies and products recommended by similar people the most. However, in the next research as much as $64 \%$ of the respondents preferred information obtained from experts and scientists (Dorenda-Zaborowicz, 2012, p.69).
Additionally, this research indicated that the best effects in social media are obtained by marketing campaigns based on reliable building of trust and prestige. The sender of such information becomes a leader, taking the position of a "trusted adviser", what, as N. Linnell states, launches the mechanism thanks to which the users buy the product, recommend it in the network or/and promote in the Internet, trusting that it is based on true intention (Linnell, 2010). Therefore, when leading to the utilization of the potential of virtual community, the company has to take actions aimed at creating a positive market perception of its resources, having reflection in, among others: high market value of a brand and distinctive reputation of the company. Consequently, we deal with a long-term process that is directed to a systematic development of such relationships that translate into capital supply for the company.

The participants of virtual communities while playing the role of: recipients, senders or information relays, become the company's customers, what, in consequence, means the possibility of basing mutual relationship on the $4 \mathrm{C}$ formula adopted for the customer value management, encompassing 4 links: customer satisfaction, customer loyalty, customer value and customer orientation (figure 3). 


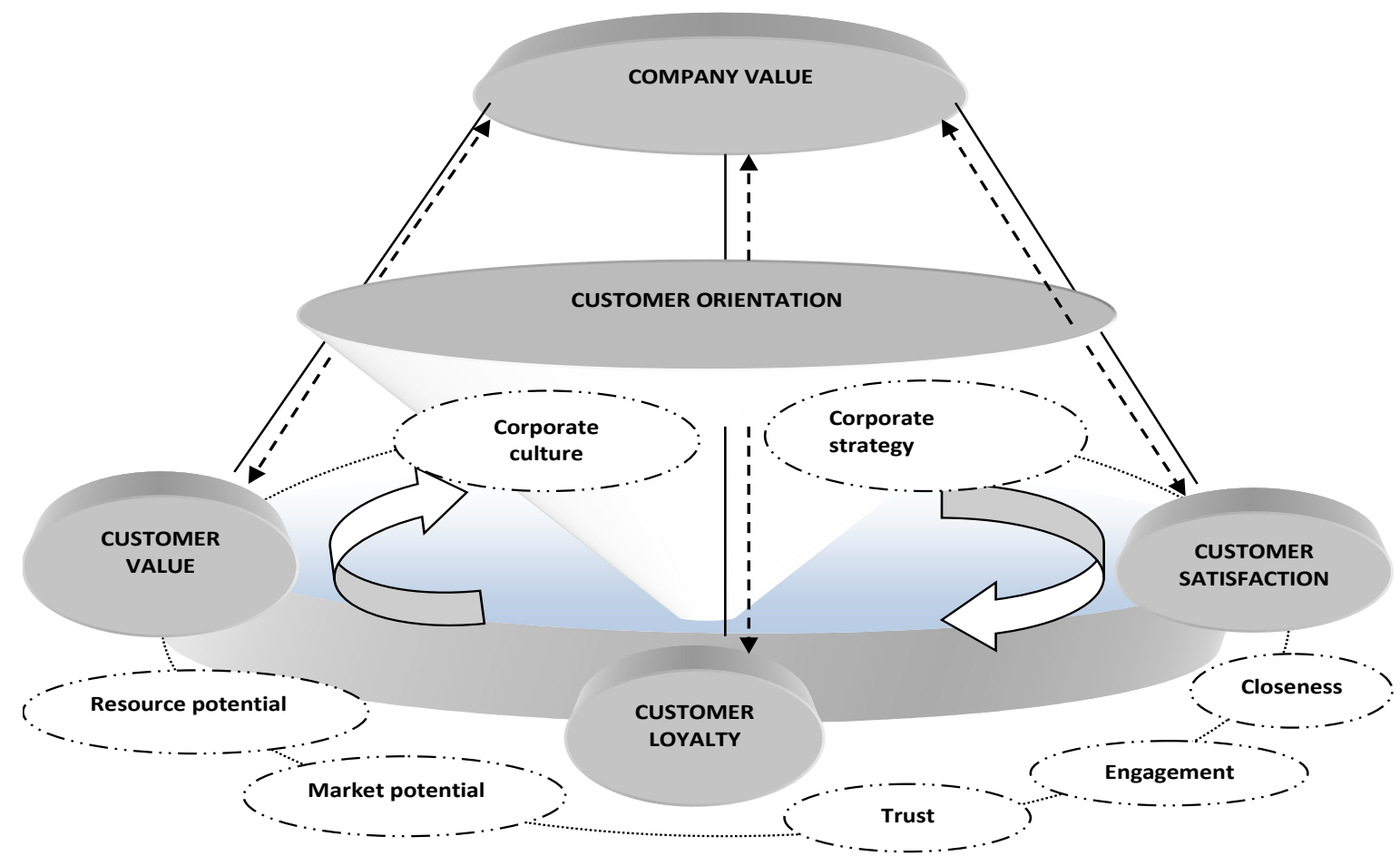

Figure 3 Key links of customer management - 4C formula

Source: own work based on: Helm and Günter, 2006, p.11

The fact is out of discussion that on the competitive market the customer satisfaction is a starting point of transferring the contact with the customer into a permanent relationship and tie. Nevertheless, it does not guarantee that the relationship will be permanent, what as a result, inclines the company to take actions aimed at customer loyalty creation. The way to this objective leads through putting the customer in such chain of relationships that introduces an emotional assessment in the place of rational assessment of the enterprise and its products offered (Storbacka, et al., 1994, p.26, West et al. 2006, p.18). The increase in customer engagement in the process of value creation changes the character of ties that link him/her with the company. The customer, co-generating value, and being his/her user at the same time, becomes an integral part of the company along with the development of the relationship, what translates into confidence increase and what follows it, permanent relationships and immunity to activities of competitive subjects.

Not every customer is able to supply the company with capital to the same extent. Not every virtual community possesses the same potential in terms of capital supply. As a result, introduction of the aforementioned formula in practice means the necessity of measuring the customer (community) value, what should also involve his/her readiness and ability to launch and develop information and knowledge resources that may be a contribution to the process of value creation, with the inclusion of customer life cycle. A good business model should present such a concept of activity that provides the enterprise with the opportunity to generate the competitive advantage.

Indeed, obtaining and developing the intellectual potential of virtual communities requires management, what means the necessity of identifying the factors determining its effective utilization for the achievement of business objectives. In the set of these factors, beside such determinants as: professional project preparation or clear problem statement, the following ones are indicated: business complexity and specificity, product brand. However, organizational culture gains special significance (Gassmann et al., 2012, p.181).

This culture, being a system of thinking and acting patterns embedded in social environment, bases on 
subconscious, often unwritten rules that fill the space between the rules set and reality (Zbiegień-Maciąg, 2002, p.2).

The use of Internet communities in the process of customer capital creation requires generating the resource of organizational culture. The key features of this culture are: activity, cooperation and engagement of all subjects representing both demand and supply side of the relationship in the process of value creation (Caputa, 2015b, p.158). The foundations of such culture is the partnership that enables a systematic balance between the customer's and company's interests, becoming at the same time a provider of permanent capital supply. In consequence, organizational culture of the enterprise that leads to benefits maximization coming from gaining and developing the potential of Internet communities, must be fully open to the customer and its creation triggers not only changes in the way of management subordinate to "customer logics" but also changes in the system of key values and perception of the external world, including the customer role and significance. Achievement of this effect is not possible when the customer value is only a background or a component justifying the declared set of values, rules or behavior patterns.

\section{Conclusions}

A dynamic development of virtual communities and social media more and more often forces the company to take action aimed at using their reference and information-cooperation potential. This aspiration is fully justified. Internet communities, basing on the chain of relationships, in the way of information transfer, may develop knowledge resources about the company and its products as well as co-create value, and in effect develop the business knowledge resources. Moreover, using the potential of virtual communities, the enterprise may trigger synergy effects deriving from resources combination. However, it does not mean that each initiative ends up in success (Gassmann et al., 2012, p.175).

When pointing out the reason for this state of things, it should be reminded that the status of participant in the social media determines the involvement of participants in the content creation and transfer, and as a result, effectiveness of the transfer (Anderson
2006, pp. 73-740). This status bases on reputation and position in a group. Thus, if the company wants to obtain capital supply through launching and developing the potential of virtual communities, it must offer a unique value. These days knowledge is the basis of this value, and customer is its source and the relationship based on favorable value exchange is the carrier. Therefore, an integral element of the concept of customer capital management is such organizational culture in which the customer is a partner that the value is created and co-created for (Skowron and Skowron 2012, p.147). A lack of such culture should be considered as a primary barrier of the effective utilization of Internet communities in building the customer capital (Caputa, 2016, pp.133135).

One should not forget either that the virtual communities are differed by the knowledge potential of their participants. In consequence, when using the Internet community for the business purpose, the company must: clearly state its objectives concerning the use of virtual community, influence, if possible, on the selection of its participants, what is connected with the assessment of customer resource potential, select the information obtained as well as motivate the network participants to such activity that results in the desired information transfer. Therefore, an effective utilization of Internet communities in the process of building customer capital is connected with the necessity of strategy development that should constitute an integral part of a global strategy of company value creation, especially if its effects should be reflected in a distinctive corporate reputation. Nevertheless, it should be emphasized that both creating the organizational culture open to customer as well as developing and implementing the strategy of using the potential of virtual community based on social prestige requires a systematic knowledge gathering and development with users cooperation and involvement. In consequence, the knowledge barrier of both sides of the relationship makes its development and obtaining benefits impossible.

\section{References}

Anderson C., 2006, The Long Tail-how Endless Choice is Creating Unlimited Demand, (New York: Random House). 
Bielecki I., 2006, Współczesny marketing, Filozofia, strategie, instrumenty. (Warszawa,Wydawnictwo Studio EMKA).

Bliemel F.W., Eggert A., 1998, Kundenbindung aus Kundensicht. In: Kaiserslauterer Schifenreihe Marketing, edited by F.W. Bliemel, Heft no 4.

Burszta W., 2003, Internetowa polis w trzech krótkich odsłonach. In: Ekran, mit, rzeczywistość, edited by W. Buszta (Warszawa).

Bywalec Cz., 2007, Konsumpcja w teorii i praktyce gospodarowania, (Warszawa: PWN).

Caputa W., 2008, Orientacja na klienta a efektywność wykorzystania zasobów. In: Rachunkowość i finanse podmiotów gospodarczych, edited by W. Caputa, (Warszawa: Wydawnictwo CeDeWu).

Caputa W., 2015a, Pomiar kapitału klienta w kontekście kreowania wartości przedsiębiorstwa, (Warszawa, Wydawnictwo CeDeWU).

Caputa W., 2015b, Kapitał klienta w budowaniu wartości przedsiębiorstwa, (Warszawa: Wydawnictwo CeDeWu).

Caputa W., 2016, Crowdsourcing w procesie kreowania kapitału klienta. In: Dylematy rozwoju nauk o zarządzaniu. Perspektywa metodologiczna, edited by P. Bartkowiak, A. Jaki, (Toruń: TNOIK).

Caputa W., 2007, Koszt satysfakcji klienta jako wyznacznik siły konkurencyjnej przedsiębiorstwa. In: Marketing w gospodarce opartej na wiedzy, edited by Figiel S., (Olsztyn: Uniwersytet WarmińskoMazurski).

Cornelsen J., 2000, Kundenwertanalysen im Beziehungsmarketing. Theoretische Grundlegungen und Ergebnisse einer empirischen Studie im Automobilbereich, (Nürnberg).

Doligarski T., 2006, Wartość portfela klientów aspekt teoretyczny. In: Współczesne źródła wartości przedsiębiorstwa, edited by Dobiegała-Korona B., Herman A. (Warszawa: Difin).

Dorenda-Zaborowicz M., 2012, Marketing w social media. Studia i rozprawy, Nowe Media no 3, pp. 69

Doyle P., Marketing wartości. (Warszawa: Felberg SJA).

Franke N., Piller F.T., 2004, Value Creation by Toolkits for User Innovation and Design: The Case of the Watch Market, Vol. 21, Issue 6, 401-415.

FRIDRIECHS-SCHMIDT S., 2006, Kundenwert aus Sicht von Versicherungsunternehmen, (Wiesbaden: Deutscher Universitäts-Verlag ).

Gassmann O., Winterhalter S., Wecht Ch.H., 2012, Praktische durchführung: Hürden und Tipps. In: Crowdsourcing - Innovationsmanagement mit Schwarmintelligenz, (München: Hanser).
Havas Prosumer Report, 2014, The New Consumer and The Sharing Economy, vol. 18,: Date of access: 15./04/2016 http://www.sustainablebrands.com.

Helm S., Günter B., 2006, Herausforderungen der Bewertung von Kundenbeziehungen. In:, Kundenwert. Grundlagen - Innovative Konzepte Praktische Umsetzungen, edited by Helm S., Günter B. (Wiesbaden: Gabler Verlag).

Herstatt C., 1991, Anwender als Quellen für Produktinnovation, (Zürich: ADAG Administration \& Druck).

Kaplan R.S., Norton D.P., 2002, Strategiczna karta wyników. Jak przełożyć strategię na działanie, (Warszawa: Wydawnictwo Naukowe PWN).

Koss J., 2010, Sponsorowane społeczności internetowe. Zeszyty Naukowe Uniwersytetu Szczecińskiego, Ekonomiczne problemy usług no 55, (Szczecin, Wydawnictwo Uniwersytetu Szczecińskiego).

Linnell N., 2010, Social Media Influrence on Consumer Behavior, Date of access: 20/04/2016 Http://searchenginewatch.com/3640221.

Nowak J., 2012, Social media jako sieci obiegu przekazów medialnych, Studia i rozprawy, Nowe Media no 3 (Toruń: Wydawnictwo Naukowe Uniwersytetu Mikołaja Kopernika).

Prahaland, C.K., Ramaswamy V., 2000, Co-opting Customer Competence. Harvard Business Review, January-February,

Reichwald R., Piller F.T., 2006, Interaktive Wertschöpfung - Open Innovation, Individualisierung und neue Formen der Arbeitsteilung, (Wiesbaden: Gabler Verlag).

Roch C.H., 2005, The Dual Roots of Opinion Leadership. The Journal of Politics 67, No 1.

Rudawska E., 2008, Znaczenie relacji z klientami w procesie kształtowania wartości przedsiębiorstwa, (Szczecin: Uniwersytet Szczeciński).

Sandholm L., 1997, Total Quality Management, (Lund: Chartwell-Bratt).

Schneider N.C., 2007, Kundenwertbasierte Effizienzmessung. Der Beitrag von Marketingmaßnahmen zur Unternehmenswerterhöhung in der Automobilindustrie, 1 Auflage, (Wiesbaden: Gabler Verlag).

Skowron S., Skowron Ł., 2012, Lojalność klienta a rozwój organizacji., (Warszawa: Difin).

Storbacka, K. Stradvik T., Grönroos Ch., 1994, Managing Customer Relationship for Profit. International Journal of Service Industry Management, no 5.

Szczepańska K., 2010, Budowa wartości klienta w zarządzaniu jakością. In: Zarządzanie wartością klienta. Pomiar i strategie, edited by B. Dobiegała- 
Korona, T. Doligarski, (Warszawa: Wydawnictwo Poltext).

Szwajca D., Gorczyńska A., 2013, Communication of company with the environment in process building reputation, Časopis Znalostní Společnosti. Mezinárodní vědecký časopis / Journal Of Knowledge Society. International scientific journal, no 2.

Tang J., Yang H, 2006, Emergent user roles and perceived requirements in a social-oriented community. Library Review, Vol. 55, no. 8.

Tomczak T., Rudolf-Sipötz E., 2003, Bestimmungsfaktoren des Kundenwertes. Ergebnisse einer branchenübergreifenden Studie. In: Kundenwert, Grundlagen - Innovative Konzepte Praktische Umsetzungen, edited by B. Günter, S. Helm, (Wiesbaden: Gabler Verlag).
Vernette E., 2004, Targeting Women's Clothing Fashion Opinion Leaders in Media Planning An Application for Magazines. Journal of Advertising Research, March, pp. 90.

Von Hippel E., 1986, Lead Users: A Source of Novel Product Concepts. Management Science, 32/7.

Wellman B., Gulia M., 1997, Net Surfers Don't Ride Alone: Virtual Communities as Communities. (New York) pp. 15, Date of access: 20/04/2012, http://www.chass.utoronto.ca/wellman/publications/n etsurfers/netsurfers.pdf.

West D., Ford J., Ibrahim E., 2006, Strategic Marketing. Creating Competitive Advantage. (New York: Oxford University Press).

Zbiegień-Maciąg L., 1999, Kultura w organizacji, (Warszawa: PWN). 